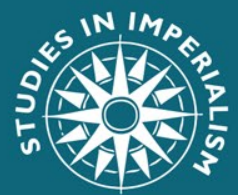 \\ EXITING WAR
}

\section{The British Empire and the 1918-20 moment}

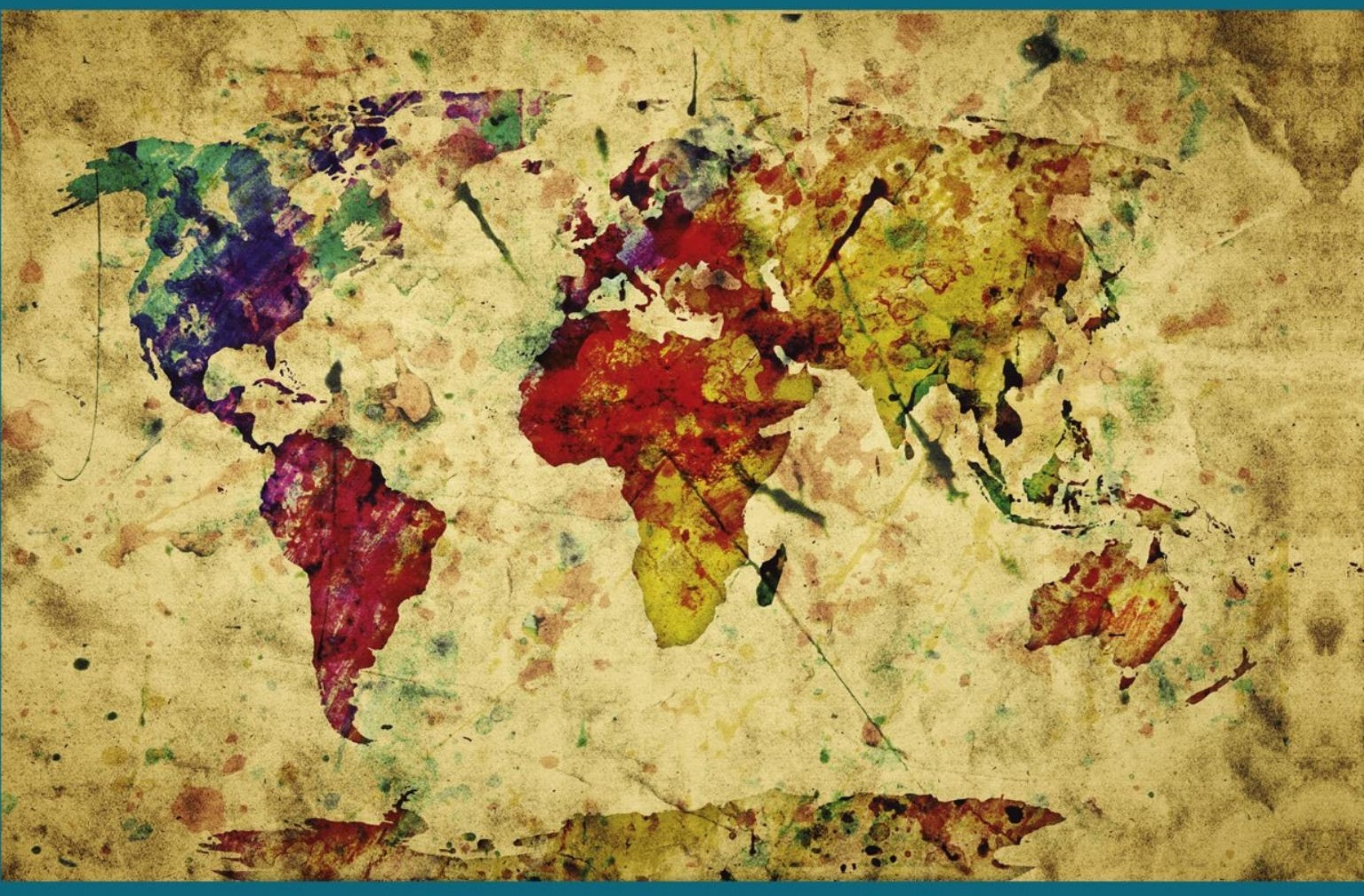

EDITED BY ROMAIN FATHI, MARGARET HUTCHISON, ANDREKOS VARNAVA AND MICHAEL J. K. WALSH 


\section{\begin{tabular}{l}
-STUDIES IN- \\
IMPERIALISM \\
\hline
\end{tabular}}

General editors: Andrew S. Thompson and Alan Lester Founding editor: John M. MacKenzie

When the 'Studies in Imperialism' series was founded by Professor John M. MacKenzie more than thirty years ago, emphasis was laid upon the conviction that imperialism as a cultural phenomenon had as significant an effect on the dominant as on the subordinate societies'. With well over a hundred titles now published, this remains the prime concern of the series. Cross-disciplinary work has indeed appeared covering the full spectrum of cultural phenomena, as well as examining aspects of gender and sex, frontiers and law, science and the environment, language and literature, migration and patriotic societies, and much else. Moreover, the series has always wished to present comparative work on European and

American imperialism, and particularly welcomes the submission of books in these areas. The fascination with imperialism, in all its aspects, shows no sign of abating, and this series will continue to lead the way in encouraging the widest possible range of studies in the field. 'Studies in Imperialism' is fully organic in its development, always seeking to be at the cutting edge, responding to the latest interests of scholars and the needs of this ever-expanding area of scholarship.

\section{Exiting war}

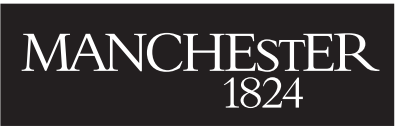

Manchester University Press 
To buy or to find out more about the books currently available in this series, please go to: https://manchesteruniversitypress.co.uk/series/studies-in-imperialism/ 


\title{
Exiting war
}

\section{The British Empire and the 1918-20 moment}

\author{
Romain Fathi \\ Margaret Hutchison \\ Andrekos Varnava \\ Michael J. K. Walsh
}


Copyright (C) Manchester University Press 2022

While copyright in the volume as a whole is vested in Manchester University Press, copyright in individual chapters belongs to their respective authors, and no chapter may be reproduced wholly or in part without the express permission in writing of both author and publisher.

Published by Manchester University Press Oxford Road, Manchester, M13 9PL www.manchesteruniversitypress.co.uk

British Library Cataloguing-in-Publication Data A catalogue record for this book is available from the British Library

\section{ISBN 9781526155849 hardback}

First published 2022

The publisher has no responsibility for the persistence or accuracy of URLs for any external or third-party internet websites referred to in this book, and does not guarantee that any content on such websites is, or will remain, accurate or appropriate.

Cover image: Vintage World Map, 2015

(C) Michal Bednarek, bednarek-art.com

Cover design: riverdesignbooks.com

Typeset

by New Best-set Typesetters Ltd 